\title{
The Types and Indications of Cholecystectomy in Nigeria: Our Experience in Damaturu, North-Eastern Nigeria
}

\author{
Aliyu $\mathrm{S}^{1}$ and Ningi $\mathrm{AB}^{2 *}$ \\ ${ }^{1}$ Department of surgery, University of Maiduguri Teaching Hospital, Nigeria \\ ${ }^{2}$ Department of Surgery, Abubakar Tafawa Balewa University Teaching Hospital, Nigeria
}

*Corresponding author: Ningi AB, Department of Surgery, Abubakar Tafawa Balewa

University Teaching Hospital, Bauchi state, Nigeria.
Received Date: June 4, 2020

Published Date: June 18, 2020

\begin{abstract}
Background: Hepato-biliary disease, especially gallbladder related, was hitherto considered an exclusive problem of the developed nations of Europe, North-America and Asia. The African continent has changed remarkably, and globalisation has brought with it a cultural change in Africa This change is characterised by both cultural and nutritional transition. The largely starch rich carbohydrate diet of the African is replaced by high calorie, fat laden meals with accompanying consumption of sugar rich snacks and beverages. The African continent has therefore seen a rise in gallbladder related pathologies and the indications and types of gallbladder related surgeries have also changed.
\end{abstract}

Objective: To determine the indications and types of cholecystectomies performed over an 11-year period at the State Specialist Hospital Damaturu, Yobe state, Nigeria.

Patients and Methods: A prospective cross-sectional study of 31 patients that presented at the General surgery unit of the State Specialist Hospital Damaturu, Yobe state, Nigeria. It is an 11-year study of patients that presented with clinically, radiologically, and histologically diagnosed Cholecystitis between 2003-2013. Patients' characteristics studied included the age, gender, clinical symptoms, risk factors, radiological tool of assessment, type of surgery performed, and types of post-operative complications observed. Informed consent was obtained according to the Helsinki guidelines and Ethical clearance was given by the hospital management. All data obtained was assessed using the Statistical Package for Social Sciences, version 20.0 (IBM, Armonk, NY, USA).

Results: A total of 31 patients were studied. 12(38.7\%) were males and 19(61.3\%) were females. The mean age of the patients is $40.5(+-3.1)$ with peak age between 26-35 years and an age range of 16-75 years. The most common clinical symptom is right hypochondriac pain, typically a biliary colic, except for acute Cholecystitis where the pain last longer. It is seen in $100 \%$ of the patients. The least common clinical symptoms are Fever (29.0\%) and Vomiting (35.5\%). All diagnosed cases where confirmed by abdominal Ultrasonography (USS). All the patients had Open Cholecystectomy. The most common indications for Cholecystectomy are chronic calculous Cholecystitis (61.3\%) followed by chronic acalculous Cholecystitis (25.8\%). The most common post-operative complication is Surgical Site Infection (SSI) at $6.5 \%$, as majority suffered no complications (80.6\%).

Conclusion: Chronic calculous Cholecystitis is the most common indication for cholecystectomy in Nigeria and open cholecystectomy is the most practiced surgery except at tertiary health facilities with expertise for laparoscopic procedures.

Keywords: Types and Indications; Cholecystectomy; North-Eastern Nigeria

\section{Introduction}

Cholecystectomy, the surgical removal of gallbladder, is reported to be the most commonly performed surgical procedure

in the general surgery units in Europe and North-America [1]. Gallbladder related diseases are however reported to be rare 
amongst the African population [2,3]. There is an evident rise in the prevalence of Gallbladder diseases in Africa. This rise however, pale in comparison to what is seen in Europe and North-America. The rise has been attributed to adoption of Western dietary habits and increased longevity [4,5]. The two main pathologies of the gallbladder seen in Africa are Cholecystitis and Cholelithiasis. Acute Cholecystitis often present as surgical emergency and up to $90 \%$ of the cases are said to be Acute Calculous Cholecystitis. The remaining $10 \%$ are acute acalculous cases and these are said to result from Salmonella Typhi related Cholecystitis, Uraemia, or systemic spread of Infection in the Immunosuppressed individuals $[6,7]$. Gallstones are biochemically differentiated into black pigment, brown pigment, and cholesterol stones [8]. Black pigment stones are composed of bilirubin and calcium and are seen in patients with recurrent haemolysis. These include patients with sickle cell disease and other haemoglobinopathies. Brown pigment stones contain bilirubin, calcium, amorphous material, and mucous glycoprotein. They are more common in Asia. Cholesterol stones are gallstones that consist of 70-90\% cholesterol by weight. These are the predominant gallstones in the West. Gallstones seen in Africans contain lesser amounts of cholesterol. Gallstones in Cameroon contain less than $25 \%$ of cholesterol with higher proportion of amorphous material [9]. A report from Ghana indicated that a 34\% of patients had cholesterol stones [10]. Microlithiasis and sludge are other source of Cholecystitis in Europe and North-America requiring similar treatment to macroscopic stones [11].

Although Cholecystectomy is the most commonly performed surgical procedure in developed nations [12], previous reports from Nigeria have indicated a rarity for the common gallbladder related diseases and placed cholecystectomy as usually a one-off surgical procedure $[13,14]$. We did this prospective cross-sectional study to assess the prevalence of these common gallbladder related diseases, types and indications of cholecystectomy in the NorthEastern part of Nigeria and compared the results with reports from other parts of Nigeria, rest of Africa and the developed countries of Europe and North-America.

\section{Patients and Methods}

A prospective cross-sectional study of 31 patients that presented at the General surgery unit of the State Specialist Hospital Damaturu, Yobe state, Nigeria. It is an 11-year study of patients that presented with clinically, radiologically, and histologically diagnosed Cholecystitis between 2003-2013. Patients' characteristics studied included the age, gender, clinical symptoms, risk factors, type of surgery performed, and types of post-operative complications observed. Abdominal USS was universally used as radiological tool of diagnosis. Past medical history was taken. All patients on Aspirin or other NSAIDS were asked to suspend treatment for 4 weeks, those on warfarin for 4 days and those on unfractionated heparin or low molecular weight heparin for 4 hours if there is no risk for Deep Venous Thrombosis. Informed consent was obtained according to the Helsinki guidelines and Ethical clearance was given by the hospital management. All data obtained was assessed using the Statistical Package for Social Sciences, version 20.0 (IBM, Armonk, NY, USA). Continuous variables were presented as mean \pm SD. Categorical variables were expressed as frequencies and percentages. The Pearson's chi square test was used to determine the relationship between two categorical variables. $\mathrm{P}<0.05$ was considered statistically significant.

\section{Results}

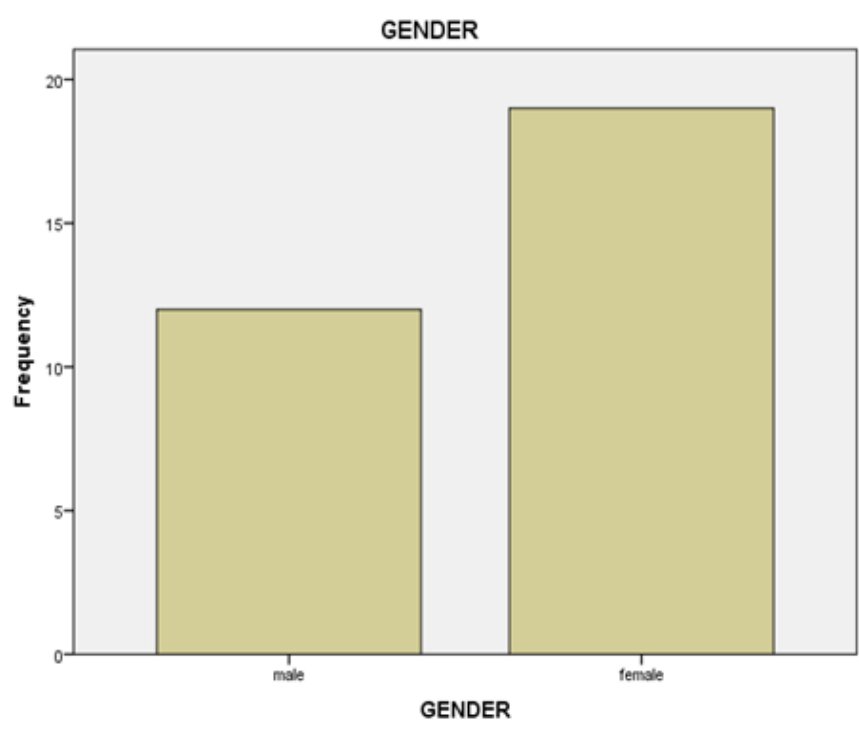

Figure 1: Showing the gender distribution of the patients. 


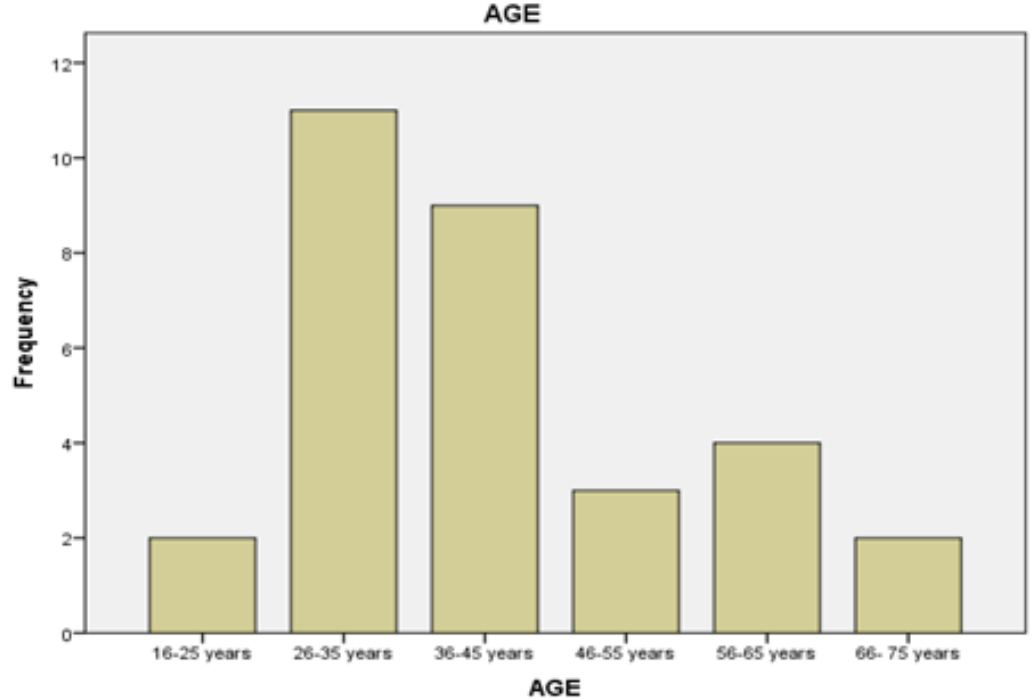

Figure 2: Showing the age distribution of the patients.

A total of 31 patients presented at the general surgery unit of the State Specialist Hospital Damaturu in Yobe state, Nigeria with clinical, radiological, and histopathological diagnosis of Cholecystitis. 12(38.7\%) were males and 19(61.3\%) were females, giving a male-female ratio of 1:2 (Figure 1). The mean age of the patients is $40.5(+3.1)$ with peak age between $26-35$ years and an age range of 16-75 years (Figure 2). The most common presenting symptom is Epigastric pain, mainly in form of biliary colic that last for some minutes to an hour. It was seen in $100 \%$ of the patients.
Nausea was seen in $67.7 \%$ of the patients and vomiting in $35.5 \%$ of the patients. A total of $29 \%$ of the patients presented with fever, generally, a low-grade intermittent type except in cases of acute Cholecystitis and gangrenous Cholecystitis. The fever is high grade, intermittent and high grade continuous with intermittent spikes and chills, respectively. Jaundice was seen in $38.7 \%$ of the patients, mainly intermittent, non-progressive, with no associated pruritus, passage of dark-coloured urine or pale, bulky, foul-smelling stool. Almost half of the patients (48.4\%) had a history of flatulence.

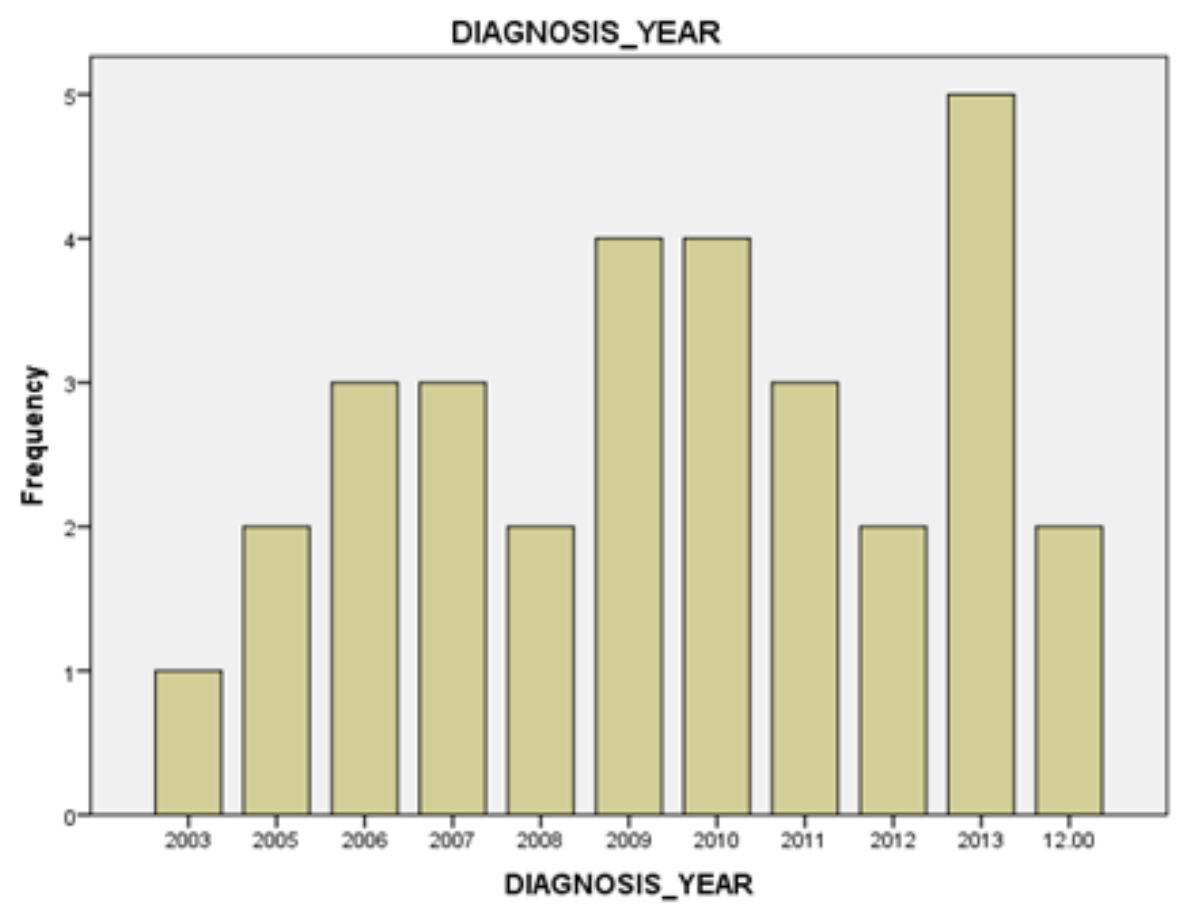

Figure 3: Showing a rising trend of the incidence per year. 
About $87.1 \%$ of the cases were chronic Cholecystitis, with chronic calculous Cholecystitis predominance at $61.3 \%$, followed chronic acalculous Cholecystitis at $25.8 \%$. Acute acalculous and necrotising Cholecystitis occurred at $3.2 \%$ each. There was a single case $(3.2 \%)$ of a finding of normal gallbladder (Table 1 ) All clinically and radiologically diagnosed cases were confirmed by histological analysis of surgically removed gallbladder A rising trend in incidence per year was noticed over the 11-year period (Figure 3). There were some intermittent dips over the years corresponding to years of escalation in the Boko Haram related armed Insurgency. The most common risk factor noted is the gender of the patient. A total of $61.3 \%$ of the patients were females with a mean age of 40 years and often multi-parous (Table 2). Majority of the patients are either civil servants, business people or farmers, indicating an

Table 1: Showing the distribution of diagnosis (Histological).

\begin{tabular}{|c|c|c|}
\hline Diagnosis & Frequency & Percent \\
\hline acute acalculous Cholecystitis & 1 & 3.2 \\
\hline chronic acalculous Cholecystitis & 8 & 25.8 \\
\hline chronic calculous Cholecystitis & 19 & 61.3 \\
\hline gangrenous Cholecystitis & 1 & 3.2 \\
\hline granulomatous Cholecystitis & 1 & 3.2 \\
\hline normal gallbladder & 1 & 3.2 \\
\hline Total & 31 & 100 \\
\hline
\end{tabular}

Table 2: Showing the role of gender in the aetiology of Cholecystitis.

\begin{tabular}{|c|c|c|c|c|c|c|c|}
\hline \multirow[b]{2}{*}{ Gender } & \multicolumn{6}{|c|}{ Histology } & \multirow[b]{2}{*}{ Total } \\
\hline & $\begin{array}{l}\text { acute acalculous } \\
\text { Cholecystitis }\end{array}$ & $\begin{array}{l}\text { chronic acalculous } \\
\text { Cholecystitis }\end{array}$ & $\begin{array}{l}\text { chronic calculous } \\
\text { Cholecystitis }\end{array}$ & $\begin{array}{c}\text { gangrenous Cho- } \\
\text { lecystitis }\end{array}$ & $\begin{array}{l}\text { granulomatous } \\
\text { Cholecystitis }\end{array}$ & $\begin{array}{l}\text { normal gall- } \\
\text { bladder }\end{array}$ & \\
\hline male & 1 & 3 & 7 & 0 & 0 & 1 & 12 \\
\hline \multirow{2}{*}{ female } & 0 & 5 & 12 & 1 & 1 & 0 & 19 \\
\hline & 1 & 8 & 19 & 1 & 1 & 1 & 31 \\
\hline
\end{tabular}

$P=0.005, X^{2}=0.485$, not statistically significant

Table 3: Showing the relationship between occupation and Cholecystitis.

\begin{tabular}{|c|c|c|c|c|c|c|c|}
\hline \multirow[b]{2}{*}{ Occupation } & \multicolumn{6}{|c|}{ Histology } & \multirow[b]{2}{*}{ Total } \\
\hline & $\begin{array}{l}\text { acute acalculous } \\
\text { cholecystitis }\end{array}$ & $\begin{array}{c}\text { chronic acalcu- } \\
\text { lous cholecys- } \\
\text { titis }\end{array}$ & $\begin{array}{c}\text { chronic calcu- } \\
\text { lous cholecys- } \\
\text { titis }\end{array}$ & $\begin{array}{l}\text { gangrenous Cho- } \\
\text { lecystitis }\end{array}$ & $\begin{array}{l}\text { granulomatous } \\
\text { Cholecystitis }\end{array}$ & $\begin{array}{c}\text { normal gall- } \\
\text { bladder }\end{array}$ & \\
\hline farmer & 0 & 3 & 3 & 0 & 0 & 1 & 7 \\
\hline business & 1 & 1 & 2 & 0 & 1 & 0 & 5 \\
\hline civil servant & 0 & 2 & 6 & 0 & 0 & 0 & 8 \\
\hline student & 0 & 1 & 4 & 0 & 0 & 0 & 5 \\
\hline \multirow{2}{*}{ unemployed } & 0 & 1 & 4 & 1 & 0 & 0 & 6 \\
\hline & 1 & 8 & 19 & 1 & 1 & 1 & 31 \\
\hline
\end{tabular}

$P=0.005, X^{2}=0.431$, not statistically significant.

Table 4: Showing the relationship between diet and Cholecystitis.

\begin{tabular}{|c|c|c|c|c|c|c|c|}
\hline \multirow{2}{*}{ Staple Diet } & \multicolumn{5}{|c|}{ Histology } \\
\cline { 2 - 8 } & $\begin{array}{c}\text { acute acalculous } \\
\text { Cholecystitis }\end{array}$ & $\begin{array}{c}\text { chronic acalculous } \\
\text { Cholecystitis }\end{array}$ & $\begin{array}{c}\text { chronic calculous } \\
\text { Cholecystitis }\end{array}$ & $\begin{array}{c}\text { gangrenous Cho- } \\
\text { lecystitis }\end{array}$ & $\begin{array}{c}\text { granulomatous } \\
\text { Cholecystitis }\end{array}$ & $\begin{array}{c}\text { normal gall- } \\
\text { bladder }\end{array}$ & $\begin{array}{c}\text { Total } \\
\text { rice }\end{array}$ \\
\hline & 0 & 3 & 4 & 0 & 0 & 1 & 8 \\
\hline maize & 1 & 2 & 8 & 0 & 1 & 0 & 12 \\
\hline
\end{tabular}




\begin{tabular}{|c|c|c|c|c|c|c|c|}
\hline sorghum & 0 & 1 & 5 & 1 & 0 & 0 & 7 \\
\hline \multirow{2}{*}{ spaghetti } & 0 & 2 & 2 & 0 & 0 & 0 \\
\cline { 2 - 8 } & 1 & 8 & 19 & 1 & 1 & 1 \\
\hline
\end{tabular}

$P=0.005, X^{2}=0.681$, not statistically significant

Table 5: Showing relationship between oral contraceptives and Cholecystitis.

\begin{tabular}{|c|c|c|c|c|c|c|c|c|}
\hline \multirow{2}{*}{\multicolumn{2}{|c|}{$\begin{array}{l}\text { acute acalculous chole- } \\
\text { cystitis }\end{array}$}} & \multicolumn{6}{|c|}{ Histology } & \multirow{3}{*}{$\begin{array}{c}\text { Total } \\
6 \\
\end{array}$} \\
\hline & & \multirow{2}{*}{$\begin{array}{c}\text { chronic acalculous } \\
\text { cholecystitis }\end{array}$} & \multirow{2}{*}{$\begin{array}{c}\text { chronic calculous } \\
\text { cholecystitis }\end{array}$} & \multirow{2}{*}{$\begin{array}{c}\begin{array}{c}\text { gangrenous } \\
\text { Cholecystitis }\end{array} \\
2\end{array}$} & \multirow{2}{*}{$\begin{array}{c}\begin{array}{c}\text { granulomatous } \\
\text { Cholecystitis }\end{array} \\
1 \\
\end{array}$} & \multirow{2}{*}{$\begin{array}{c}\begin{array}{c}\text { normal gall- } \\
\text { bladder }\end{array} \\
0 \\
\end{array}$} & \multirow[b]{2}{*}{0} & \\
\hline \multirow{3}{*}{$\begin{array}{l}\text { Oral_Contra- } \\
\text { ceptive }\end{array}$} & yes & & & & & & & \\
\hline & \multirow{2}{*}{ no } & 1 & 5 & 17 & 0 & 1 & 1 & 25 \\
\hline & & 1 & 8 & 19 & 1 & 1 & 1 & 31 \\
\hline
\end{tabular}

$P=0.005, X^{2}=0.185$, not statistically significant

Table 6: Showing relationship of haemoglobinopathies with Cholecystitis.

\begin{tabular}{|c|c|c|c|c|}
\hline \multirow{2}{*}{ Histology } & \multicolumn{3}{|c|}{ Co_Morbidity } & \multirow{2}{*}{ Total } \\
\hline & sickle cell disease & haemoglobinopathies & none & \\
\hline \multirow{2}{*}{$\begin{array}{l}\text { acute acalculous } \\
\text { Cholecystitis }\end{array}$} & 0 & 0 & 1 & 1 \\
\hline & & & & \\
\hline chronic acalculous Cholecystitis & 0 & 0 & 8 & 8 \\
\hline chronic calculous Cholecystitis & 1 & 1 & 17 & 19 \\
\hline gangrenous Cholecystitis & 0 & 0 & 1 & 1 \\
\hline granulomatous Cholecystitis & 0 & 0 & 1 & 1 \\
\hline \multirow{2}{*}{ normal gallbladder } & 1 & 0 & 0 & 1 \\
\hline & 2 & 1 & 28 & 31 \\
\hline
\end{tabular}

$P=0.005, X^{2}=0.101$, not statistically significant

Table 7: Showing relationship between defunctioning gastric surgeries and Cholecystitis.

\begin{tabular}{|c|c|c|c|}
\hline \multirow{2}{*}{ Histology } & \multicolumn{2}{|c|}{ Previous_Surgery } & \multirow{2}{*}{ Total } \\
\hline & gastric surgery & none & \\
\hline acute acalculous Cholecystitis & 0 & 1 & 1 \\
\hline chronic acalculous Cholecystitis & 1 & 7 & 8 \\
\hline chronic calculous Cholecystitis & 0 & 19 & 19 \\
\hline gangrenous Cholecystitis & 0 & 1 & 1 \\
\hline granulomatous Cholecystitis & 0 & 1 & 1 \\
\hline \multirow{2}{*}{ normal gallbladder } & 0 & 1 & 1 \\
\hline & 1 & 30 & 31 \\
\hline
\end{tabular}

$P=0.005, X^{2}=0.704$, not statistically significant

Table 8: Showing the distribution of post-operative complications.

\begin{tabular}{|c|c|c|}
\hline Complication & Frequency & Percent \\
\hline SSI & 2 & 6.5 \\
\hline haemorrhage & 1 & 3.2 \\
\hline bile duct injury & 1 & 3.2 \\
\hline bile leak & 1 & 3.2 \\
\hline keloidal scar & 1 & 3.2 \\
\hline none & 25 & 80.6 \\
\hline Total & 31 & 100 \\
\hline
\end{tabular}

\section{Discussion}

Cholecystitis, the inflammation of the gallbladder, is subclassified in to acute and chronic types depending on the presentation and the duration of symptoms. Acute Cholecystitis present as surgical emergency with sudden onset of a right hypochondriac pain and other symptoms and up to $90 \%$ are said to be associated with 
gallstones [15]. The Prevalence of Cholelithiasis by Autopsy studies in white Americans is said to be $30 \%$ and only $10 \%$ of these stones are symptomatic [15]. Akute in Ibadan, South-West of Nigeria reported a tertiary hospital-based prevalence of $1.79 \%$ in 2002 [16]. This demonstrated a significant rise in prevalence over 5 decades. He reported an incidence of $0.007 \%$ in 1965 . The prevalence in our report in 2003 was 2.1\% and this rose to 13\% in 2013. Adedeji in Lagos, South-West of Nigeria also reported a rising incidence of Cholelithiasis in Lagos [17]. A report from Ghana, West-Africa, also indicated a twelve-fold increase in the incidence of Cholelithiasis over 5 years, 1989-1994 [4]. A report by Loffler from East-Africa also indicated a steady rise in incidence among indigenous African population living in urban areas [18], and reports from SouthAfrica also indicated a rising incidence of Cholelithiasis among Black South-Africans, by indicating a 10\% prevalence among 100 patients assessed by abdominal Ultrasonography [19,20]. The true incidence of Gallbladder diseases in Africa is not known, because many patients are managed as cases of Peptic Ulcer disease at Primary and Secondary Tier health centres. The use of Ultrasonography and higher resolution radiological tools improve the odds of getting the right diagnosis at tertiary health centres.

Out of the 31 patients studied, 12(38.7\%) were males and $19(61.3 \%)$ were females, giving a male-female ratio of 1:2 (Figure 1). There is an apparent predilection of the female gender to benign Gallbladder diseases. Our finding of Female to male ratio is in keeping with other reports in Africa and other parts of the world $[13,21,22]$ A report from Calabar, South-Southern Nigeria, indicated a female-male ratio of $5: 1[23,24]$. This may be a result of a smaller sample size of 24 patients in the first report and differences in dietary pattern in the second report. The mean age is 40.5 with a peak age at 26-35 years (Figure 2). This is in keeping with report from Zaria, North-Central of Nigeria [13]. It is however, less than the peak years seen in Ibadan and Lagos (60-69 years), South-Western Nigeria [14,16] and Enugu (60-69 years), South-Eastern Nigeria [25]. In the male, the peak incidence in Sudan is at 50-59 years [26], and 60-69 years in Uganda [27]. In Caucasians, the peak age of incidence is at 50-60 years [15], and in the West Indies $40 \%$ of the patients present at 20-30 years of age due to early and multiple pregnancies [28]. The early age of onset in Northern Nigeria may be because of early marriages, often at the age of 17-18 years and multiparity.

Diagnosis was established through clinical history and examination, use of Ultrasonography, and confirmed by histopathological report of removed gallbladders. Right upper quadrant pain was present in $100 \%$ of the patients mainly in form of biliary colic that last for some minutes to an hour and Murphy's sign was positive in $71 \%$ of the patients. Sauquoit in Calabar, SouthSouthern Nigeria reported the presence of right upper quadrant in $94.4 \%$ and positive Murphy's sign in 55.6\% [23]. Nausea was seen in $67.7 \%$ of the patients and vomiting in $35.5 \%$ of the patients. A total of $29 \%$ of the patients presented with fever, generally a lowgrade intermittent type except in cases of acute Cholecystitis and gangrenous Cholecystitis. The fever is high grade, intermittent and high grade continuous with intermittent spikes and chills, respectively. Jaundice was seen in $38.7 \%$ of the patients, mainly intermittent, non-progressive, with no associated pruritus, passage of dark-coloured urine or pale, bulky, foul-smelling stool. Almost half of the patients $(48.4 \%)$ had a history of flatulence. These Symptoms were similar to those reported by other workers [29]. However, other studies in Nigeria reported no presence of Jaundice [23].

About $87.1 \%$ of the cases were chronic Cholecystitis, with chronic calculous Cholecystitis predominance at $61.3 \%$, followed by chronic acalculous Cholecystitis at $25.8 \%$. Acute acalculous and necrotising Cholecystitis occurred at $3.2 \%$ each. There was a single case $(3.2 \%)$ of a finding of normal gallbladder (Table 1). This is similar to reports from other parts of Nigeria. Asuquo in Calabar reported an incidence of $50 \%$ for chronic calculous Cholecystitis and $44.4 \%$ for chronic acalculous Cholecystitis [23]. Although, the incidence of Cholelithiasis in Africa is less than what is seen among Caucasians, most Africans present with calculous Cholecystitis than acalculous type. This is attributed to the preponderance of anatomical anomalies in the Hepato-Billiary tree, late presentation, and blockage in extra-hepatic Billiary tree by Parasites and their Ova $[23,30]$. Ascaris Lumbricoides is regularly reported as a cause of obstruction of the extra hepatic billiary tree. Others include Clonorchis sinensis and Schistosoma Mansoni [30]. Most of the stones are pigment stones. A biochemical analysis of stones from South-Western part of Nigeria also indicated preponderance of the pigmented stones (40\%) [30]. This is similar to previous reports of up to $46 \%$ by Ajao in Ibadan, South-West, Nigeria [31]. The stones are jet-black, granular, and multiple. The remaining are mixed stones, which are brownish and multi-faceted. Pure pigment stones are also reported in Kinshasa, Congo [32], Kampala-Zimbabwe [33], and Uganda [34]. Report from Sudan however, indicated predominance of pure cholesterol stones [35], and white Bile is also reported to be common among Sudanese patients with Gallstones [26]. The large pool of black pigment stones seen in the black African population is related to the prevalence of haemolytic disorders such as, sickle cell disease, G6PD deficiency and Endemic Malaria parasitaemia [33,34]. This finding is similar to our own, where $6.4 \%$ of the patients have sickle cell disease and $3.2 \%$ have G6PD deficiency (Table 6). With a p-value of 0.101, the relationship is however, not statistically significant.

Abdominal USS is the radiological tool of diagnosis in $100 \%$ of the patients. It was chosen because of availability, affordability, and presence of expertise for conduction and interpretation of result. Although there is wide gamut of diagnostic tests for the 
detection of gallbladder stones, the transabdominal ultrasound US is the gold standard for diagnosis of Cholelithiasis [36]. It has sensitivity and specificity $>95 \%$ for stones greater than $1.5 \mathrm{~mm}$ in size and is excellent in providing information on the number and mobility of stones, gallbladder volume, wall thickness and size of the common bile duct. Useful information on other intra-abdominal organs can be obtained also. USS is said to be more sensitive than CT Scan or MRI for gallstones [37]. Although, abdominal USS is very sensitive for common bile duct size, it may not be able to detect small common duct stones (sensitivity $<50 \%$ ). Most tertiary health centres therefore, deploy alternative imaging where necessary. Endoscopic retrograde cholangiopancreatography (ERCP) is a highly sensitive and specific imaging modality, but it is invasive and requires considerable training. It associated with post-procedure morbidity that is operator dependent. It may result in pancreatitis, excessive primary haemorrhage or secondary bleeding and perforation of duodenum, occur each in $5-8 \%$ of patients most especially, after endoscopic sphincterotomy (ES) and the mortality rate is $0.5-0.8 \%$. This is not available in the whole of Northern Nigeria. It is only available at Obafemi Awolowo University Teaching Hospital, Ile-Ife, South-Western Nigeria [30]. Magnetic-resonancecholangio-pancreatography (MRCP), is considered to have slightly lower accuracy and no therapeutic value. But, because it is noninvasive, it has lower morbidity than ERCP. Sadly, it is unavailable in Northern Nigeria also and generally unavailable in most African countries [38]. Nuclear imaging facility, like HIDA scans, has been used to identify a blocked cystic duct often associated with acute Cholecystitis but, this is also unavailable in most lowincome countries [38]. Although, gender (Table 2) $\mathrm{P}=0.005, \mathrm{X} 2=$ 0.485 ) and Haemoglobinopathies (Table 6) $\mathrm{P}=0.005, \mathrm{X} 2=0.101$ ) were identified as risk factors for Cholelithiasis, other factors were also noted. Majority of the patients are either civil servants, business people or farmers, indicating an association of gallbladder disease with higher social class (Table 3) P- 0.005, X2 $=0.431$, not statistically significant). This finding is in keeping with other reports that indicated a higher prevalence among the affluent patients of Europe and North-America [1]. Chronic acalculous Cholecystitis was also reported to constitute $44.4 \%$ of the study population in Calabar, Nigeria [23], and others reported 35\%-37\% in Nigerians with gallbladder disease $[13,39]$. This may be attributable to a functional deficiency in gallbladder emptying mechanism $[40,41]$. The staple diet is predominantly grain, consisting of maize $(38.7 \%)$, rice $(25.8 \%)$ and sorghum $(22.6 \%)$, in keeping with low fat, starch rich African diet (Table 4) $\mathrm{P}=0.005, \mathrm{X} 2=0.681$, not statistically significant). This is similar to other reports explaining the relative rarity of Gallbladder diseases and the low prevalence of pure cholesterol stones in black Africans [30,31].

A total of $31.6 \%$ of the female patients used oestrogen containing oral contraceptives (Table 5) $\mathrm{P}=0.005, \mathrm{X} 2=0.185$, not statistically significant). This finding has been affirmed by other reporters.42 One patient (3.2\%) had previous truncal vagotomy for chronic gastric ulcer (Table 7) $\mathrm{P}=0.005, \mathrm{X} 2=0.704$, not statistically significant). This result from denervation due to injury to the hepatic branch of the left Vagus nerve. There are some theories implicating genetic predisposition as a cause of gallbladder stones but, the definitive genes are yet to be identified [42]. The causes of acute and chronic acalculous Cholecystitis are varied in Africa. In our patients' case an association with chronic Salmonella Typhi infection has been found and in one patient he continued to excrete Typhoid bacilli after Cholecystectomy. Percutaneous liver biopsy confirmed hepatic origin of the infection. This is similar to numerous reports establishing an association between both acute and chronic acalculous Cholecystitis with Salmonella Typhi infection [43-48].

All the patients were treated by open Cholecystectomy due to lack of facility for Laparoscopic Cholecystectomy. This is in stark contrast to developed nations of the world were Laparoscopic Cholecystectomy is the gold standard unless there is an absolute contraindication [49]. The Laparoscopic Cholecystectomy although desirable it is fraught with some difficulties. The NIH (National Institute of Health) Consensus Conference held in 1992, stated that "Laparoscopic cholecystectomy is safe and effective in most of the cases but can be technically demanding, is not free of complications and has some inherent disadvantages" [50]. Many factors may render Laparoscopic Cholecystectomy difficult and may result in conversion to Open Cholecystectomy. Laparoscopic Cholecystectomy is considered difficult pre-operatively in the presence of the following Ultrasonographic findings: Contracted Gallbladder, Gallbladder wall thickness $>4 \mathrm{~mm}$, Gallstone impacted in the neck of the Gallbladder and Common Bile Duct diameter $>8$ $\mathrm{mm}[50]$.

There were very few post-operative complications. Only $6.5 \%$ of the patients developed SSI, while 3.2\% developed excessive primary haemorrhage, bile duct injury, bile leak and keloidal scar, each (Table 8). The risk for SSI for Open Cholecystectomy was placed at $7.6 \%$ based on the American College of Surgeons Risk Calculator-August 2, 2015 [51]. The Bile Duct injury and Leakage was noticed on post-operative day 5 and 12 respectively. The reported rate for Bile Duct injury and leakage was $0.5 \%$ and it is said to occur between 1 week to 6 months after the surgery [5153]. Billiary injury and fistula most likely result because majority of our cases were the chronic type (87.1\%). There was no perioperative mortality; the average duration of hospital stay was 1 week. Prolonged hospital stay was due to surgical site infection and biliary fistula. The billiary fistula closed spontaneously. This is similar to reports from other parts of Nigeria [23].

\section{Conclusion}

Gallbladder disease, especially gallstone, although less common than what is seen in the West, has an upward trend of 
incidence in Nigeria. Abdominal USS is an effective diagnostic tool and chronic calculous Cholecystitis is the most common indication of Cholecystectomy in Nigeria. Open Cholecystectomy is a safe alternative of treatment where facility for Laparoscopic Cholecystectomy is not available.

\section{Acknowledgement}

None.

\section{Conflict of Interest}

No conflict of interest.

\section{References}

1. Vogt DP (2002) Gallbladder disease: an update on diagnosis and treatment. Cleveland Clinic Journal of Medicine 69(12): 977-984.

2. Badoe EA, Archampong EQ da Rocha Afodu JT (2000) Principles and practice of surgery, including pathology in the tropics and subtropics. Ghana Publishing Cooperation. Tema pp. 704.

3. Gelfand M (1981) The incidence of gallstones in Zimbabwe. Cent Afr J Med 27: 46-47.

4. Darko R, Archampong EQ (1994) Changing pattern of Cholelithiasis in Accra. West Afr J Med 13: 204-208.

5. Akute 00, Obajimi MO (2002) Cholelithiasis in Ibadan: an update. West Afr J Med 21: 128-131.

6. Huffman JL, Schenker S (2010) Acute acalculous Cholecystitis: A review. Clin Gastroenterol Hepatol 8: 15-22.

7. Avalos ME, Cerulli MA, Lee RS (1992) Acalculous acute Cholecystitis due to Salmonella Typhi. Dig Dis Sci 37: 1772-1775.

8. Dowling RH (2000) Review: pathogenesis of gallstones. Aliment Pharmacol Ther 2: 39-47.

9. Angwafo FF, Takongmo S, Griffith D (2004) Determination of chemica composition of gall bladder stones: basis for treatment strategies in patients from Yaoundé, Cameroon. World J Gastroenterol 10(2): 303305.

10. Darko R, Archampong EQ, Qureshi Y, Muphy GM, Dowling RH (1919) How often are Ghanaian gallbladder stones cholesterol-rich. West African Journal of Medicine 19(1): 64-70.

11. Jungst C, Kullak-Ublick GA, Jungst D (1920) Gallstone disease: Microlithiasis and sludge. Best Pract Res Clin Gastroenterol 20(6): 10531062.

12. Moreaux J (1994) Prospective study of open cholecystectomy for calculous biliary disease. Br J Surg 8: 116-119.

13. Dauda MM, Yusufu LMD, Attah MM (2005) Cholecystitis and Cholelithiasis in adults in Zaria. Trop Doct 35: 243-245.

14. da Rocha Afodu JT, Adesola AO (1971) Cholecystitis in Nigerians. Journa of Nigerian Medical Association 1: 45-50.

15. Adelola A, Opeoluwa OD, Oluyombo AA (2000) Davey's Companion to Surgery in Africa: Hepatobiliary System. Acecool Medical Publishers pp. 316-335.

16. Akute 00, Obajimi MO (2002) Cholelithiasis in Ibadan: An Update. West Afri J Med 21(2): 128-131.

17. Adedeji A, B Akande, F Olumide (1986) The changing pattern of Cholelithiasis in Lagos. Scand J Gastroenterol Suppl 124: 63-66.

18. Loefler IJP (1986) Gallstones and Glaciers: Hypothesis melting at the Equator. Lancet 2: 283

19. D Parekh, H H Lawson, J M Kuyl (1987) Gallstone disease among SouthAfricans. A Review of the Baragwaneth Hospital experience. South Afri Med J 72: 23-26.
20. AR Walker, I Segal, R Posner, H Shein, NG Tsotetsi, et al. (1989) Prevalence of Gallstones in elderly Black women in Soweto, Johannesburg as assessed by Ultrasonography. AM J Gastroenterol 84(11): 1383-1385.

21. Allen J, Cuschieri A (2005) Cholelithiasis. E-Medicine pp. 1-12.

22. Gladden DO, Migala AF (2005) Cholecystitis. E-Medicine pp. 1-22.

23. ME Asuquo, MS Umoh, V Nwagbara, A Inyang, C Agbor (2008) Cholecystectomy: Indications at University of Calabar Teaching Hospital, Calabar, Nigeria. Ann Afr Med 7(1): 35-37.

24. Sharper AC, Patel MK (1964) Diseases of the biliary tract in Africans in Uganda. East Afr Med J 41: 246-250.

25. Ojukwu JO, Okafor JC (1999) Incidence of Cholecystitis and Cholelithiasis seen in UNTH, Enugu, Nigeria. Journal of College of Medicine 4: 84-86.

26. El-Masri SH, Ahmed ZE (1976) Cholelithiasis in Sudanese patients. Sudan Med J 14-23.

27. Sharper AC, Patel MK (1964) Diseases of the biliary tract in Africans in Uganda. East Afr Med J 41: 246-250.

28. walrond ER (1973) Gallbladder diseases at the University Hospital, Jamaica. West Ind Med J 22: 119-124.

29. Jackson PG, Evans S (2012) Billiary System. In: Townsend CM Jr, Beauchamp RD, Evers BM, Mattox KL (eds.), Sabiston Textbook of Surgery ( $19^{\text {th }}$ edn.), Philadelphia, PA: Saunders Elsevier.

30. Ajayi PA, Lawal OO (1997) Chemical composition of Gallstones in Nigerians. Central Afri J Med 43(10): 293-295.

31. Ajao OG (1982) Cholecystitis and Cholelithiasis in a tropical African population. Trop Doc 12: 164-166.

32. Luigi F (1928) Annales de la Societe Belge de Medicine Tropicale. PP. 8: 311.

33. Owor R (1964) Gallstones in the autopsy population at Mulago Hospital, Kampala. East Afri Med J 41: 251-253.

34. Kawooya M (1992) Gallstones in Uganda Africans undergoing Ultrasonography. Proc. Ass. Surg. East Afr 1: 76-77.

35. Suleiman SI (1977) Cholelithiasis in Khartoum. Sudan Med J 15: 48.

36. Portincasa P, Moschetta A, Petruzzelli M, Palasciano G, Di Ciaula A, et al. (1920) Gallstone disease: Symptoms and diagnosis of gallbladder stones. Best Practice \& Research in Clinical Gastroenterology 6: 10171029.

37. Gore RM, Yaghmai V, Newmark GM, Berlin JW, Miller FH (2002) Imaging benign and malignant disease of the gallbladder. Radiologic Clinics of North America 40(6): 1307-1323.

38. Kaltenthaler E, Vergel YB, Chilcott J, Thomas S, Blakeborough T, et al. (2004) A systematic review and economic evaluation of magnetic resonance cholangiopancreatography compared with diagnostic endoscopic retrograde cholangiopancreatography. Health Technology Assessment (Winchester, England) 8(10): iii, 1-89.

39. Amaral J, ZL Xiao, Q Chen, P Yu, P Biancani, et al. (2001) Gallbladder muscle dysfunction in patients with chronic acalculous disease. Gastroenterology. 120: 506-511.

40. Adams DB, Tarnasky PR, Hauves RH, JT Cunningham, C Brooker, et al. (1998) Outcome after laparoscopic cholecystectomy for chronic acalculous Cholecystitis. Am Surg 64: 1-5.

41. Frezza EE, Mezghebe H (1997) Gallbladder carcinoma. A 28-year experience. Int Surg 82: 295-300.

42. Nakeeb A, Cumuzzi AG, Martin L, Gabriele E Sonnenberg, Debra SwartzBasile, et al. (2002) Gallstones: genetics versus environment. Ann Surg 235: 842-849.

43. Vaishnavi C, Singh S, Kochhar R, Bhasin D, Singh G, et al. (2005) Prevalence of Salmonella enterica serovar typhi in bile and stool of patients with biliary diseases and those requiring biliary drainage for other purposes. Jpn J Infect Dis 58: 363-365. 
44. Menendez A, Arena ET, Guttmann JA, Thorson L, Vallance BA, et al. (2009) Salmonella infection of gallbladder epithelial cells drives local inflammation and injury in a model of acute typhoid fever. J Infect Dis 200: $1703-1713$.

45. Slim MS, Fakhri S, Bitar J, Musallam S, Uwaydah M (1988) Acute abdomen in Salmonella infection. Pediatr Surg Int 3: 47-50.

46. Verma M, Chhatwal J, Deodhar MC, Aneja R, Singh T (1995) Enteric Cholecystitis 15-year-experience. Indian Pediatr 32: 808-810.

47. Tsakayannis DE, Kozakewich HP, Lillehei CW (1996) Acalculous Cholecystitis in children. J Pediatr Surg 31: 127-130.

48. Chirdan LB, Iya D, Ramyil VM, Sule AZ, Uba AF, et al. (2003) Acalculous Cholecystitis in Nigerian children. Pediatr Surg Int 2003; 19: 65-67.

49. Duca S, Bala O, Al-Hajjar N, C Lancu, IC Puia, et al. (2003) Laparoscopic Cholecystectomy: Incidents and Complications. A Retrospective Analysis of 9542 consecutive Laparoscopic Operations. HPB(Oxford) 5(3): 152158.
50. Praveen K, Rajiv NS (2019) Prediction of Difficult Laparoscopic Cholecystectomy Based On Preoperative Ultra-Sonographic Findings. Int J Recent Sci Res 10(11): 36049-36052.

51. http://riskcalculator.facs.org

52. Nawaz H, papachristou GI (2011) Endoscopic treatment of PostCholecystectomy Bile leaks: updates and recent advances. Ann Gastroenterol 24(3): 161-163.

53. Society for Surgery of the Alimentary Tract (2004) Treatment of Gallstone and Gallbladder Disease. SSAT Patient Care Guidelines. J Gastrointest Surg 8(3): 363-364. 